\title{
Experimental evidence for sex-based palatability variation in fourwing saltbush
}

\author{
DIONNE MAYWALD, E. DURANT MCARTHUR, GARY L. JORGENSEN, RICHARD STEVENS, AND SCOTT C. \\ WALKER
}

Authors are doctoral candidate, Departments of Botany and Environmental Science and Management, University of Adelaide, South Australia 5005; research geneticist and project leader, Shrub Sciences Laboratory, Rocky Mountain Research Station, USDA Forest Service, Provo, Ut. 84606; range technician, Great Basin Experimental Range, Rocky Mountain Research Station, USDA Forest Service, Ephraim, Ut. 84627; wildlife biologist and project leader, Great Basin Research Center, Division of Wildlife Resources, Utah Department of Natural Resources, Ephraim, Ut. 84627; wildlife biologist, Great Basin Research Center, Division of Wildlife Resources, Utah Department of Natural Resources, Ephraim, Ut 84627.

Abstract

Two small-plot grazing trials were conducted in the spring of 1996 and the winter of 1997 to determine whether sheep would differentially graze fourwing saltbush [Atriplex canescens (Pursh) Nutt.] on the basis of shrub sex in a uniform garden. Consumption was determined using an Australian method of leaf tagging in conjunction with the Adelaide Technique of biomass estimation. The results confirmed anecdotal field observations that herbivores prefer to graze the male shrub during late spring. No sex based preference was apparent during winter. We suggest that differences in physiological vigor and/or chemistry may influence relative palatability of the sexes through time. Results of these experiments contrast with those for an Australian member of the genus (A. vesicaria Hew. ex Benth.), for which it was found that the female was the preferred phenotype throughout the year.

Key Words: Atriplex canescens (Pursh) Nutt., sex phenotypes, seasonal variation

Fourwing saltbush [Atriplex canescens (Pursh) Nutt.] is a widespread, subdioecious chenopod species of the western rangelands of North America (Freeman et al. 1993). It is a useful cover species and forage source for game and livestock, and has been described as a preferred forage shrub in all seasons (Plummer et al. 1966, McArthur et al. 1983,McArthur et al. 1984). Field observations suggest that there may be palatability variation within fourwing saltbush. It is thought that male plants are generally preferred by both game and livestock (Plummer et al. 1966). Cibils et al. (1997) recently reported, however, that a fourwing saltbush population that had been protected from cattle grazing had a female sex ratio bias compared to an adjacent grazed population. Cibils et al. (1997) suggested that sex-based grazing may account for this bias. Plummer et al. (1966) noted that when pre-

Authors wish to thank Stewart Sanderson, Kent Jorgensen, Dick Tennent and student volunteers for assistance with the trials, and Fleur Tiver, Leigh Hunt and Ron Hacker for reviewing the draft manuscript. This work was supported by an Australian Rangeland Society Travel Grant to the senior author and was facilitated by Pittman Robertson Wildlife Habitat Project W-82-R (Utah Division of Wildlife Resources and Rocky Mountain Research Station cooperating).

Manuscript accepted 16 Jan. 1998.

\section{Resumen}

Durante la primavera de 1996 y el invierno de 1997 tuvo lugar el apacentamiento experimental de dos peqlueñas parcelas para determinar si las ovejas diferenciaban en sus hábitos de apacentar el arbusto fourwing saltbush [Atrtiplex canescens (Pursh) Nutt] de acuerdo al sexo del arbusto, en un huerto uniforme. Se determinó el consumo usando un método australiano de marcar las hojas, junto con la Técnica Adelaide de calcular la biomasa. Los resultados confirmaron las observaciones acecdóticas de que los hervivoros prefieren apacentar el arbusto macho en la última parte de la primavera. Hacia la última parte del invierno, no parece haber una preferencia determinada. Se sugiere que las diferencias en el vigor fisiológico y la química pueden influir en el sabor relativo de los arbustos de diferente sexo a través del tiempo. El resultado de estos experimentos contrasta con aquellos realizados con uno de los miembros australianos del género (A. vesicaria Hew. ex Benth.), en el que se comprobó que el género femenino era fenotipe preferido durante todo el año.

sent, the seed utricles (borne on the female shrubs) are sought out by grazing animals. Thus, the information to date suggests that there may be temporal variability in the acceptance of male vs female fourwing saltbush shrubs.

It is possible that the sex phenotypes of fourwing saltbush do differ in their palatability, for they are known to differ in a number of other respects. Differences have been demonstrated for height and crown diameter (McArthur et al. 1992), leaf biomass (Freeman et al. 1993), branch length, number of flowers, inflorescence length (Pendleton et al. 1992) and plant longevity (Freeman et al. 1984). Furthermore, Tiedemann et al.(1987) reported that concentrations of various metabolites differed between the sexes at certain times of the year.

Given the known differences between the sexes and the apparent temporal variability, we decided to determine if sheep selectively graze the sexes of fourwing saltbush in a uniform garden. The null hypothesis in both trials was that biomass consumption from the sexes would not be disproportional to availability. 


\section{Materials and Methods}

\section{Study Area}

The experiments were conducted in a fourwing saltbush garden at Snow Field Station,immediately north-east of Ephraim (Sanpete County) Ut. The Field Station, which has been converted to agricultural use, is a former basin big sagebrush site on Woodrow silty clay loam soil (Swenson et al. 1981). It is $2 \mathrm{~km}$ west of the base of the monoclinal front of the Wasatch Plateau, at an elevation of $1,700 \mathrm{~m}$. Annual precipitation at the Station averages $270 \mathrm{~mm}$, with about $45 \%$ received as winter snow.

The fourwing saltbush garden was established in 1985 using clonally propagated ramets of known genetic origin (McArthur et al. 1992). The species is subdioecious, monoecious and labile plants were excluded to produce a garden consisting of male and female plants only. The garden was set up as a grid of 9 rows with shrubs separated by $1.3 \mathrm{~m}$. Since establishment, the garden has received minimal cultural care and has not been grazed by livestock or wildlife.

\section{Experimental Plots}

The grazing trials were conducted in late spring (8-14 June) 1996 and late winter (23-26 March) 1997. During spring 1996 a section of the garden was divided and fenced into 3 equal-sized plots. Each plot $(10 \mathrm{~m} \times 30 \mathrm{~m})$ was fenced with fine mesh to exclude herbivores. Three new plots were built in another section of the garden for the late-winter trial. The number of female and male shrubs within the plots differed because the garden was originally designed as a seed orchard and some shrubs had died before the experiments began (Table 1).

Table 1. Number and distribution of fourwing saltbush shrubs in the experimental plots.

\begin{tabular}{|c|c|c|c|}
\hline Seasonal & Plot & Males & Females \\
\hline Spring & $\begin{array}{l}\text { A } \\
\text { B } \\
\text { C }\end{array}$ & $\begin{array}{c}6 \\
12 \\
7\end{array}$ & $\begin{array}{l}17 \\
14 \\
16\end{array}$ \\
\hline Winter & $\begin{array}{l}\mathrm{D} \\
\mathrm{E} \\
\mathrm{F}\end{array}$ & $\begin{array}{l}5 \\
5 \\
7\end{array}$ & $\begin{array}{l}14 \\
22 \\
17\end{array}$ \\
\hline
\end{tabular}

\section{Shrub Characteristics}

Before the experiments, several features were measured to characterize the shrubs in the garden. The maximum height and width of living foliage was measured to the nearest centimeter, and the percentage of branches with current season's flowers and/or utricles was used to assign a "reproductive" category to each shrub (Table 2). In spring, both females and males were assigned a category on the basis of flowering. In late winter, females were assigned a category on the basis of residual utricles. For the males, the winter category was based on the percentage of branches with residual flowers from the previous spring.

The total biomass of each shrub was cstimated once before cach trial using a modification of the Adelaide Technique (Andrew et al. 1979). This non-destructive biomass estimation method, developed for use with chenopod shrubs in Australia, was readily adapt-
Table 2. Reproductive categories used for fourwing saltbush shrubs.

\begin{tabular}{cc}
\hline \hline Category & $\begin{array}{c}\text { Percentage of branches with } \\
\text { flowers \&/or utricles }\end{array}$ \\
\hline & $(\%)$ \\
2 & $1-20$ \\
3 & $21-40$ \\
4 & $41-60$ \\
5 & $61-80$ \\
\hline
\end{tabular}

ed to fourwing saltbush. A branch with a foliage span of about 25 $\mathrm{cm}$ was picked from a non-experimental shrub and weighed immediately (this branch is called a Hand Held Unit, or HHU). The number of HHU equivalents which approximated the leaf and stem biomass of each experimental shrub was visually estimated. The HHU was taken back to the laboratory after all estimations were completed, and the leaves and young stems were stripped off. The woody remainder was weighed and subtracted from the initial fresh weight to provide an estimate of the fresh weight of the leaves and non-woody stems. This final weight was then multiplied by the HHU estimations to produce fresh weight estimates of the leaf and stem biomass for each shrub.

\section{Estimation of Biomass Consumption}

Biomass consumption was estimated using the microdot method (Lange 1984). A water-based acrylic paint was used to mark small $(2 \mathrm{~mm})$ dots on a sample of external leaves on each experimental shrub. Marked leaves were used to represent the consumable foliage of each shrub. This representation is valid if the dots are distributed evenly (with respect to foliage density) over the accessible biomass (Lange 1984). At the end of each grazing period, the dots remaining on the shrubs were counted. Thus, the microdot method and the non-destructive biomass technique were used together to estimate the amount of fourwing saltbush biomass consumed by the sheep.

We used an approximate guide of 1 marked leaf per hand-sized area of foliage for the fourwing saltbushes in the garden, Variations in foliage density required some adjustment to this guide. Dots were only applied to living, animal-accessible foliage. To aid relocation, the dots were a bright color and were placed on terminal leaves. It has been shown that small colored dots of this nature do not influence the grazing behavior of sheep (Lange 1984). To identify the branches with marked leaves, a small paint slash was applied near the base of the stem. In the spring experiment, microdot application and biomass estimation were restricted to $1.5 \mathrm{~m}$. However, we found that the sheep could only reach to $1.2 \mathrm{~m}$, so the numbers of non-accessible dots and the weights of non-accessible biomass were subtracted from the totals to provide estimates of what was available to the sheep. For this reason, biomass estimation and microdot application in the winter trials were limited to $1.2 \mathrm{~m}$ in height.

\section{Animals}

Once surveying, biomass estimation and microdot application were completed, sheep were introduced to the plots. For spring trials, 10 yearling ewes were borrowed from a farm in Sanpete Valley near Ephraim. The sheep had not experienced fourwing saltbush before, but had been grazing on greasewood [Sarcobatus vermiculatus (Hook.) Torr.], trident saltbush [Atriplex tridentata 
Table 3. Comparison of shrub characteristics $(\bar{x} \pm S E)$ for the sexes of fourwing saltbush prior to grazing.

\begin{tabular}{|c|c|c|c|}
\hline \multirow[b]{2}{*}{ Characteristic } & Shrub Sex & \multirow[b]{2}{*}{ Female } & \multirow[b]{2}{*}{ Significance } \\
\hline & Male & & \\
\hline \multicolumn{4}{|l|}{ Spring 1996} \\
\hline Height $(\mathrm{cm})$ & $154 \pm 6$ & $147 \pm 4$ & $P>|t|=0.38$ \\
\hline Width (cm) & $247 \pm 15$ & $249 \pm 11$ & $P>|Z|=0.83$ \\
\hline Fresh Weight (g) & $540.4 \pm 74.7$ & $622.9 \pm 54.4$ & $P>|Z|=0.29$ \\
\hline \multicolumn{4}{|l|}{ Winter 1997} \\
\hline Height $(\mathrm{cm})$ & $148 \pm 9$ & $139 \pm 5$ & $P>|t|=0.34$ \\
\hline Width $(\mathrm{cm})$ & $255 \pm 21$ & $258 \pm 12$ & $P>|Z|=0.85$ \\
\hline Fresh Weight (g) & $311.5 \pm 87.7$ & $674.7 \pm 49.7$ & $P>|Z|=0.001$ \\
\hline
\end{tabular}

Kuntze], and shadscale [A. confertifolia (Torr. \& Frem.) S. Wats.]. To overcome any potential lack of experience, the sheep were allowed to graze on fourwing saltbush shrubs in a holding yard adjacent to the experimental plots for 12 hours before the first replicate of each trial.

\section{Spring Trials}

The sheep were put into Plot A at 0800 on Day 0 and left to graze with access to water for about 23 hours. On the morning of Day 1 the sheep were quietly mustered into the holding yard, and the number of microdots remaining on the shrubs was counted. Marked leaves which had been broken from the shrubs and not eaten (due to rejection or trampling), were discarded and subtracted from the calculations of consumption and subsequent availability. After counting was completed, the sheep were returned to Plot A for another day. This pattern was repeated for Plots B and C. Since 10 sheep depleted the biomass of the shrubs in Plot A very quickly, we halved the flock to 5 sheep for Plots B and C.

\section{Winter Trials}

The trials were conducted soon after the snow had melted at the Field Station. The shrubs did not have any new growth, but the leaves from the previous year were still present. Three of the 5 sheep used in the spring trials were relocated for the winter trials. Unfortunately, not all 5 could be found and the remaining 2 were taken from the larger flock that provided the initial sheep. The methodology used in the spring trials was repeated for the winter trials, except that the sheep spent 24 hours in each of the 3 winter plots.

\section{Analyses}

As the same sheep were not used in both trials and the grazing duration differed between the plots, the results of the spring and winter trials were analyzed separately. Linear regression was used to compare the number of microdots with the amount of biomass available for consumption for each experiment. The initial height, width, and biomass of the male and female shrubs were compared using Student's t-tests or theWilcox on two-samples tests. The latter was used when Shapiro-Wilk W tests detected serious departures from normality that could not be rectified using data transformations. The consumption of the sexes was compared by analysis of covariance, using the amount of biomass consumed from each plant as the response variable and initial biomass as the covariate. All analyses were performed using the JMP program (SAS Institute Inc. 1989).

\section{Results}

\section{Available Biomass}

Linear regressions confirmed a significant relationship between the number of microdots applied to the shrubs and their initial biomass for both trials (spring $\mathrm{r}^{2}=0.84, \mathrm{P}<0.01$, winter $\mathrm{r}^{2}=$ $0.86, \mathrm{P}<0.01$ ). The regressions confirmed that microdot application was highly consistent with shrubs receiving a suite of dots in proportion to the biomass available for consumption. The microdot and biomass estimation methods were adaptable for use with fourwing saltbush in these experiments.

\section{Spring 1996 Trial}

There was no significant difference in height, width, or biomass between female and male fourwing saltbush shrubs before grazing (Table 3). Flowering was advanced for both female and male shrubs, however male shrubs tended to have more branches with flowers than females (Fig. 1). Most of the male flowers were in the process of dehiscing. The consumption of male biomass was significantly higher than female biomass $(P<0.001)$. A comparison of the proportion of initial biomass consumed from the shrubs on a per plot basis (Fig. 2) confirmed that the sheep consistently preferred to consume male fourwing saltbushes. The covariate (initial biomass) was also significant $(P<0.001)$. To investigate the effect of the covariate, biomass consumption was regressed with initial biomass for each sex. The resulting linear regressions were highly significant (female $\mathrm{r}^{2}=0.72, \mathrm{P}<0.001$. male $\mathbf{r}^{2}=0.81, \mathrm{P}<0.001$ ), and showed that shrubs of low biomass were grazed less than shrubs of high biomass.

\section{Winter 1997 Trial}

There were no significant differences in either initial height or width between male and female fourwing saltbush shrubs in late winter (Table 3). The average initial biomass of female shrubs was significantly higher than male shrubs $(P<0.001)$. Male shrubs tended to have a lower percentage of branches with flowers compared to the shrubs used in the spring trials. This suggests that the shrubs used in the winter trials either did not flower as much as the shrubs used in the spring experiment or, more likely, that some of the spent flowers fell from the shrubs. The utricle histogram for the females in winter shows a similar pattern to that for flowers in the spring trials, with most female shrubs possessing a moderate percentage of branches with utricles. Analysis of covariance was not used to compare the consumption of the sexes in the winter trial because the initial biomass of the sexes was significantly different (thus precluding the use of initial biomass 

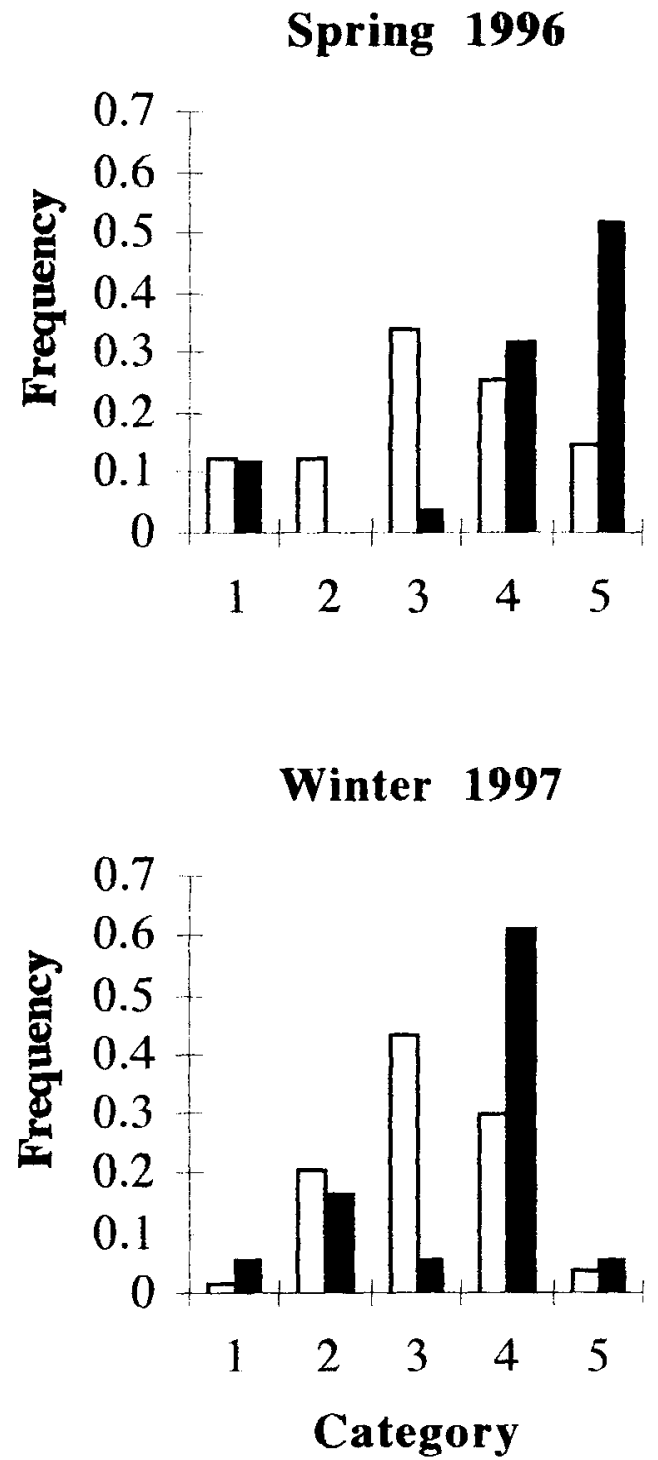

Fig. 1. Frequency histograms showing flower/utricle categories on the basis of sex for both trials (See Table 2 for definition of categories). Open columns represent females, closed columns represent males.

as a covariate). Instead, the proportion of biomass consumed from each shrub was used as the response variable in an analysis of variance. There was no significant difference in the relative consumption of biomass from male and female shrubs in the winter trial $(\mathrm{P}>0.57)$. Unfortunately, the design of the winter trial was relatively unbalanced, with many more female plants than male plants. Ideally, more male shrubs should have been included in the winter trials to provide similar sample sizes, but this was not possible due to the layout of the garden.

\section{Conclusions and Management Implications}

There were no measurable differences in either height, width, or biomass (with the exception of biomass in the winter trial) between the sexes. The lack of differences in height and biomass (spring only) contrasts with the findings of McArthur et al.

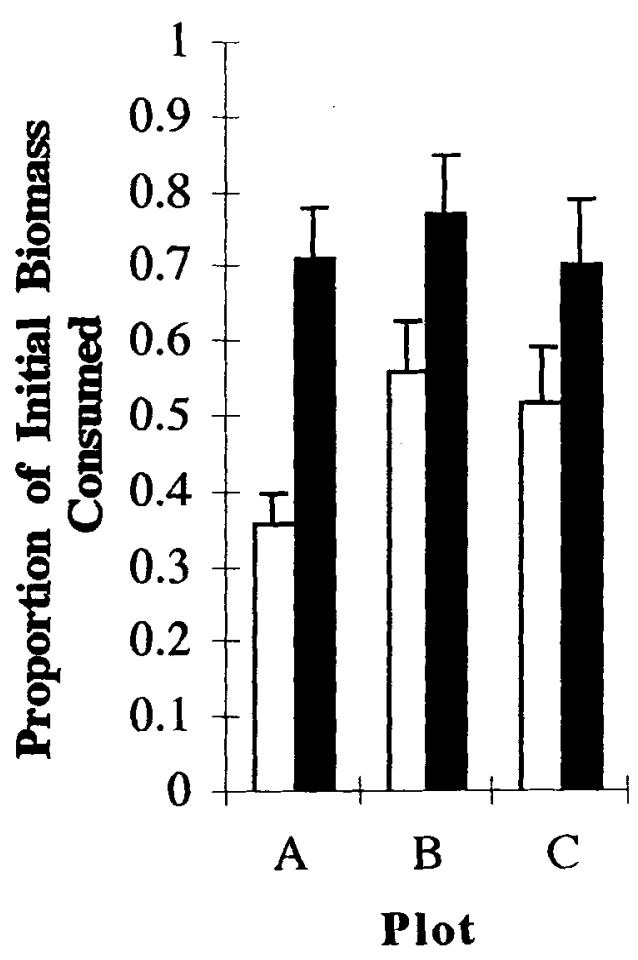

Fig. 2. Proportion of initial biomass consumed $(x \pm S E)$ from the shrubs in each experimental plot in the spring trials. Open columns represent females, closed columns represent males.

(1992) and Freeman et al. (1993) and may reflect the fact that the shrubs in the garden had not been previously grazed. Freeman et al. (1993) found that female plants had more leaf biomass than male plants in both spring and fall. Our finding that male plants had less biomass than female plants in the winter supports that trend. The similar physical structure of the sexes, combined with the lack of previous grazing, provided a standard basis from which to compare the palatability of the sexes in our study.

The sheep consistently discriminated between the sexes of fourwing saltbush during late spring 1996 by preferentially grazing male shrubs. Given that there were fewer males than females in every plot, the results suggest that the sheep sought out the male shrubs. The sheep curtailed their consumption of the more abundant female biomass in order to preferentially consume male material. This preference for male shrubs is consistent with observations made by the authors in pastures in Sanpete County. Autecological information may explain why male shrubs may be preferred by sheep during spring. Tiedemann et al. (1987) found that in late spring, the physiological vigor of male fourwing saltbush plants was higher than either female or sexually labile plants. This suggests that male plants may be relatively more active in their growth in late spring compared to the other phenotypes. If this is true, then males may be grazed heavily at this time because herbivores prefer green, succulent, young growth over mature growth (Vallentine 1990). Interestingly, Tiedemann et al. (1987) found no significant differences in physiological vigor between the sexes at any other time of the year, and we found no significant difference in the consumption of the sexes in the winter trials. As our only aim was to determine whether the sheep would selectively graze the sexes of fourwing saltbush in 
the garden, underlying nutrient and chemical differences were beyond the scope of our study.

It is interesting to note that the sex phenotypes of an Australian saltbush (A. vesicaria Hew, ex Benth.) are also grazed differentially. In contrast to the results found here, the female plant is the preferred phenotype (Graetz 1978, Williams et al. 1978). Furthermore, the selectivity is maintained throughout the year regardless of season or phenological stage (Maywald, unpublished). The continuous, and preferential consumption of the female phenotype limits seed production and has serious implications for population dynamics in A. vesicaria (Maywald, unpublished). Although seasonal grazing of the male phenotype in $A$. canescens may not significantly alter the seed output of grazed populations, other management implications (if any) remain unknown. Palatability variation within $A$. vesicaria appears to be related to chemical differences, even though the genus is regarded as relatively benign in terms of defenses (M. Ralphs, pers. comm.). Pearson et al. (1990) suggested that palatability variation in $A$. vesicaria was related to sodium levels in the foliage, with higher sodium biotypes being relatively less palatable to sheep. Our results, and those of Tiedemann et al. (1987), suggest considerable scope for investigating the role of nutrients and/or secondary chemistry in palatability variation for fourwing saltbush. In the meantime, we believe that grazing experiments need to be conducted in natural populations of fourwing saltbush to confirm the findings of the garden trials reported in this paper.

\section{Literature Cited}

Andrew, M. H., I.R. Noble, and R.T. Lange. 1979. A non-destructive method for estimating the weight of forage on shrubs. Aust. Range. J. 1: $225-231$.

Cibils, A.F., D.M. Swift, and R.H. Hart. 1997. Animal-plant interactions in an Atriplex canescens dominant community browsed by cattle. 23-24. p. In: Proc. XVIII Int. Grassl. Congr., Vol. 2. Winnipeg, Manitoba Saskatoon, Saskatchewan, Can.

Freeman, D. C., E.D. McArthur, and K.T. Harper. 1984. The adaptive significance of sexual lability in plants using Atriplex canescens as a principal example. Ann. Mo. Bot. Gard. 71: 265-277.

Freeman, D. C., E.D. McArthur, S.C. Sanderson, and A.R. Tiedemann. 1993. The influence of topography on male and female fitness components of Atriplex canescens. Oecologia 93: 538-547.

Graetz, R. D. 1978. The influence of grazing by sheep on the structure of a saltbush (Atriplex vesicaria Hew. ex Benth.) population. Aust. Range. J. 1: 117-125.

Lange, R. T. 1984. Leaf marking in rangeland grazing studies Trans. Royal Soc. South Australia 108: 213-214.

McArthur, E.D., R. Stevens, and A. C. Blauer. 1983. Growth performance comparisons among 18 accessions of fourwing saltbush (Atriplex canescens) at two sites in central Utah. J. Range Manage. 36: $78-81$.

McArthur, E. D., S.E. Stranathan, and G.L. Noller. 1984. 'Rincon' fourwing saltbush proven for better forage and reclamation. Rangelands 6: 62-64.

McArthur, E. D., D.C. Freeman, L.S. Luckinbill, S.C. Sanderson, and G.L. Noller. 1992. Are trioecy and sexual lability in Atriplex canescens genetically based?: evidence from clonal studics. Evolution 46: $1708-1721$.

Pearson, J.T., A.D. Sparrow, and R.T. Lange.1990. Prolonged exposure to sheep grazing reduces the palatability of Australian saltbush populations. Aust. J. Ecol. 15:337-344.

Pendleton, B. K., D.C. Freeman, E.D. McArthur, and R.I. Pendleton.1992. 1. Life history features of three sexual morphs of Atriplex canescens (Chenopodiaceae) clones grown in a common garden. Amer. J. Bot 79: 376-382.
Plummer, A. P., S.B. Monsen, and D.R. Christensen. 1966. Fourwing saltbush-a shrub for future game ranges. Utah Dept. Fish and Game Rep. 66-4: 1-12.

SAS Institute Inc. 1989. JMP Version 2. SAS Institute Inc. Cary, N.C.

Swenson, J.L., Jr., D. Becstrand, D.T. Erickson, C. McKinley, J.J. Shiozaki, and R. Tew. 1981. Soil survey of Sanpete Valley Area, Utah USDA-SCS and USDI/BLM, Salt Lake City, Ut. 179p. + 67 maps.

Tiedemann, A. R., E.D. McArthur, and D.C. Freeman. 1987. Variations in physiological metabolites and chlorophyll in sexual phenotypes of 'Rincon' fourwing saltbush. J. Range Manage. 40: 151-155.

Vallentine, J. F. 1990. Plant selection in grazing. p. 178-216. In: J.F. Vallentine (ed.), Grazing management. Acad. Press, San Diego, Calif.

Williams, D. G., D.J. Anderson, and K.R. Slater. 1978. The influence of sheep on pattern and process in Atriplex vesicaria populations from the Riverine Plain of New South Wales. Aust. J. Bot. 26: 381-392. 